ROCZNIKI TEOLOGICZNE

Volume LXV, issue 9 - 2018

English version

DOI: http://dx.doi.org/10.18290/rt.2018.65.9-9en

ZDZISŁAW KUPISIŃSKI SVD

\title{
RESEARCH ON FOLK RELIGIOSITY AT KUL'S DEPARTMENT OF RELIGIOLOGY AND MISSIOLOGY
}

\begin{abstract}
The article presents the historical activity, specificity and thematic scope of research conducted by faculty members and students, with a particular focus on postdoctoral (habilitation), doctoral and master's theses that were written on the subject of folk religiosity at the Department of Religiology and Missiology at John Paul II Catholic University of Lublin. In order to explain our research methodology and the method of analyzing the collected source material obtained from ethnographic field studies on social and spiritual folk culture, the article presents the main themes of the examined annual rituals (Advent, Christmas, Lent, Easter) and the rites of passage (weddings, funerals). Many of our articles on folk rituals and religiosity have been published in journals and research monographs.
\end{abstract}

Keywords: Department of Religiology and Missiology at John Paul II Catholic University of Lublin; popular piety/folk religiosity; folk customs and rituals; annual rituals and rites of passage; ethnographic field studies.

It is difficult to imagine the Polish landscape without roadside chapels and crosses, where in May, people get together and sing a litany to the Mother of God, or an October prayer service without the rosary in Church. An inseparable element of the Polish landscape includes Marian sanctuaries and temples, which have their patron saints. What exactly is religious piety and religiosity? In the Catechism of the Catholic Church, we read: "In addition to the sacrament liturgies and sacramentals, catechesis should take into account the forms of piety of the faithful and popular piety.

"The religious sense of the Christian people has always found expression in the various forms of piety that surrounded the sacramental life of the Church. They are: veneration of relics, visits to sanctuaries, pilgrimages,

Dr. Hab. Zdzisław Kupisiński SVD, KUL Prof. is the Chair of the Religiosity and Missiology Department at the Institute of Fundamental Theology at John Paul II Catholic University of Lublin. Address: ul. Jagiellońska 45, 20-806 Lublin; e-mail: dzidek@kul.lublin.pl 
processions, the Way of the Cross, religious dances, the rosary, medals, etc." (CCC 2012, 1674). ${ }^{1}$

The Catechism points out that these forms of piety are a continuation of the liturgical life of the Church, but they do not replace it. They should be organized so that they "harmonize with the liturgical seasons, in accord with the sacred liturgy, are in some way derived from it and lead the people to it, since in fact the liturgy by its very nature is far superior to any of them" (CCC 2012, 1675). Therefore, in order to sustain and support folk religiosity, pastoral discernment is needed, and if necessary, the religious sense of these forms of piety should be clarified and deepened, and then direct them to bring about a deeper knowledge of the mystery of Christ (Kupisiński 2010, 224-25).

Thus, the CCC, in referring to the Pueblo Document $(1979,448)$ and Pope Paul VI's Apostolic Exhortation Evangelii Nuntiandi 48 states that: "At its core, the piety of the people is a storehouse of values that offers answers of Christian wisdom to the great questions of life. The Catholic wisdom of the people is capable of fashioning a vital synthesis. [...] It creatively combines the divine and the human, Christ and Mary, spirit and body, communion and institution, person and community, faith and homeland, intelligence and emotion. This wisdom is a Christian humanism that radically affirms the dignity of every person as a child of God, establishes a basic fraternity, teaches people to encounter nature and understand work, provides reasons for joy and humor even in the midst of a very hard life. For the people, this wisdom is also a principle of discernment and an evangelical instinct through which they spontaneously sense when the Gospel is served in the Church and when it is emptied of its content and stifled by other interests" (CCC 2012, 1676).

Understanding religiousness and popular piety in this way, the researchers at the Department of Religiology and Missiology and students at the seminar on religious studies conduct stationary ethnographic field studies on spiritual culture, paying special attention to folk religiosity in different regions of Poland and Ukraine. The first part of this paper presents the historical activity of the Chair of Religiology and Missiology, the second presents the subject of research of our academic staff and students, with special attention paid to the postdoctoral, doctoral and master's theses created in our

\footnotetext{
${ }^{1}$ Catechism of the Catholic Church, accessed December 10, 2018: http://www.vatican.va/ archive/ccccss/archive/catechism/p2s2c4a1.htm.
} 
Department (our achievements), and the third part presents our research methods and research topics (annual rituals, rites of passage) in order to show the method of elaborating the collected source materials which come primarily from our own ethnographic field studies.

\section{ORIGINS OF THE FACULTY OF RELIGIOLOGY AND MISSIOLOGY}

The present Department of Religiology and Missiology dates back to the beginnings of KUL, when during the first meeting of the Academic Senate of the Catholic University of Lublin in the autumn of 1918, the Department of the History of Religion was erected, at the same time becoming the first chair of religious studies in Poland. Initially, its didactic activity was limited to conducting lectures for students of fundamental theology, whose lecturers were: Rev. Józef Archutowski (1918-1920), Rev. Józef Kruszyński (19301939) and Rev. Edward Bulanda (1945-1949) (Łukaszyk 1968, 5-6).

When Fr. Dr. Teofil Chodzidło SVD, ethnologist and religious scholar, was employed in the Fundamental Theology Section, the Theology Faculty Council's resolution on February 18, 1958 reactivated the work of the Department of History and Ethnology of Religion. Due to Fr. Chodzidło's specialization, the original name of the Department of History of Religion was changed to the Department of History and Ethnology of Religion, which he headed from 1961-1976. In 1973, Rev. Dr. Henryk Zimoń SVD was employed as a senior assistant in the department, and in 1975 he became an adjunct. In 1985, he became the head of the Department of History and Ethnology of Religion. An important event for the Chair was the resolution on October 15, 1985 of the Theology Faculty Council to establish a specialization in religious studies at the Department of History and Ethnology of Religions in the Section of Fundamental Theology, which began its activity in the 1985/86 academic year. From that time on, priests and graduates of theology could undertake stationary studies in various religious disciplines, with particular emphasis on religious studies (Nagy 1994, 195, Zimoń 1985, 161, ibidem 2009, 11-12).

In 1986, Krzysztof Gładkowski, MA, became a research worker and trainee assistant (in 1987 he was an assistant, since 1993 an adjunct). After K. Gładkowski resigned as an assistant in the Department, Rev. Dr. Zdzisław Kupisiński SVD was employed on October 1, 1994. In 1998, he became an 
adjunct and on November 1, 2009 he was appointed as an associate professor. On October 1, 2003, a third research worker, Rev. Stanisław Grodź, PhD, SVD, becoming an adjunct in 2007. From October 1, 2011 to September 30, 2013, Dr. Józef Nowak worked as an assistant (Zimoń 2009, 12).

After Rev. Prof. Henryk Zimoń retired on October 1, 2012, the head of the Department of History and Ethnology of Religion became Rev. Dr. Hab. Zdzisław Kupisiński SVD, a KUL professor. As a result of the reorganization of the studies program, on March 1, 2013 the Department was transformed into the Department of Religious Studies, and on June 11, 2014 it was again changed into the Department of Religious Studies and Missiology. It included three scholars and was headed by Rev. Dr. hab. Zdzisław Kupisiński SVD, KUL professor, adjunct Dr. hab. Andrzej Pietrzak SVD, and assistant professor Rev. Dr. Stanisław Grodź SVD. As a result of the reorganization at the Institute of Fundamental Theology and its previous departments of Religious Studies and Missiology and Theology of Religions, on October 1, 2016, the Department of Religiology and Missiology was established. It employs the following scholars: Rev. Dr. hab. Zdzisław Kupisiński SVD, KUL professor and the head, Fr. Dr. hab. Ireneusz S. Ledwoń OFM, KUL professor, and Fr. Dr. hab. Andrzej Pietrzak SVD, KUL professor.

\section{ACADEMIC WORK}

One of the research topics of the Chair of Religiology and Missiology at the Catholic University of Lublin is folk culture in the Slavic lands. As part of this activity, we carry out ethnographic stationary field studies on the social and spiritual culture of Poland, and some regions of Ukraine are also included in the research. The goal of our field research is to study annual, family, agrarian rituals, etc. Students of the department together with academic workers organized ethnographic camps (in Skierbieszów near Zamość, in the Gorzów Śląski deanery (diocese of Opole), in the parish in Brzegi (Diocese of Lesser Poland), on the territories of Opoczno and Radom, with regular excursions and field trips to ethnographic museums and open-air museums (including such open-air museums as the Museum of Folk Architecture in Sanok, Tokarnia near Kielce, in Bierkowice, in Kluki, the Słowiński National Park, the Kielce Countryside Museum, the Lublin Countryside Museum, the Mission and Ethnographic Museum in Pieniężno, the Museum of Folk Art in Otrębusy, the Museum of Ethnography in Warsaw, 
the Tatra Museum in Zakopane, the Regional Museum in Opoczno, the Ethnographic Museum in Krakow, the Museum of Central Pomerania in Słupsk and others) (Kupisiński 1995, 145; ibidem 2009, 176-78; ibidem 2010a, 44).

Student theses papers concentrate on issues related to Slavic religion, the popular social and spiritual cultures of Poland and Ukraine as well as new religious movements. In this field of research, Rev. Prof. Henryk Zimoń was the supervisor of 5 doctoral theses and 50 master's theses, and Rev. Dr. hab. Zdzisław Kupisiński, KUL professor supervised 2 doctoral dissertations, including one from the Nadsan and Boyka region in Ukraine, as well as 26 master's theses dealing with the issues of family and annual rituals in Poland as well as Ukraine (Zimoń 1989-1990, 252-55, ibidem 1980, 223-24; Kupisiński 2009a, 177).

Funeral problems in Poland were developed in two habilitation dissertations: Rev. Jan Perszon (On the Edge of Life and Death. Customs, Rituals, Funeral Beliefs Prayers for the Dead in Kashubia, Lublin 1999) and Rev. Zdzisław Kupisiński (Death as an Eschatic Event. Customs, Rites, Funeral Beliefs and Prayers for the Dead among Residents of the Opoczno and Radom Region, Lublin 2007), one doctoral thesis by Anna Dolata (Afterlife in Polish Folk Religiosity, Lublin 2013) and a post-graduate licentiate thesis by Karolina Kowalczyk (Customs, Rituals and Funeral Beliefs in Orchowiec's Parish in Lublin Archdiocese, Lublin 2013). In five doctoral thesis, annual customs, rituals and beliefs were explored on the territory of Pszczyna (Rev. Antoni Dudek TChr), in the Wejherowo region (Rev. Jan Perszon), in the Gorzow deanery of Gliwice diocese (Rev. Franciszek Jędrak); the period from Advent to Easter in the Opoczyński region (Rev. Zdzisław Kupisiński), in the Gródek region of the Diocese of Kamyanets-Podolia in Ukraine (Svitlana Snigurska); customs, rituals and Advent and Christmas beliefs in the Tomaszów region in the Zamość area (Józef Nowak) ${ }^{3}$; the Christmas period in the regions of Nadsania and Bojkowszczyzna in the Lviv region of Ukraine (Rev. Taras Borovets). In addition, 78 master's theses were written on various issues about the social and spiritual culture of Poland, Ukraine and Lithuania, namely: Advent and Christmas ritual themes (43 works, including one from Lithuania and Ukraine), Lent and Easter rituals (13 works),

\footnotetext{
${ }^{2}$ Rev. Z. Kupisiński's doctorate was published in two books: Adwent i Boże Narodzenie w regionie opoczyńskim. Studium religijności ludowej. Warsaw: Verbinum 1997; Wielki post i Wielkanoc w regionie opoczyńskim. Studium religijności ludowej. Warsaw: Verbinum 2000.

${ }^{3}$ J. Nowak's doctorate was published in Studiach Religiologicznych $\mathrm{nr}$ 5: Adwent i Boże Narodzenie w regionie tomaszowskim. Studium religijności ludowej. Lublin: TN KUL 2003.
} 
agrarian rites ( 5 works), funeral rituals ( 3 works), folk beliefs ( 6 works on folk demonology and one work on charms), and religious folk art (2 works). Issues related to wedding customs and rituals are taken up by Zdzisław Kupisiński and Jan Łuczkowski, the wedding customs, rituals and beliefs in Opoczyński, tradition versus contemporary times, including three master's theses and one post-graduate licentiate thesis based on other regions of Poland, the punk rock youth subculture of selected groups (one work), sects (one work) and Slavic religion (one work) (Kupisiński 2009a, 177).

The resulting works are primarily based on empirical materials collected during stationary ethnographic field studies lasting from two to three months in the case of a master's theses, from six months to a year in the case of doctoral dissertations, and for habilitation research work from twelve to fourteen months. So far, explorations have been carried out in the following regions of Poland: Kurpie Zielone, Warmia, Kociewie, Kaszuby, Greater Poland, Szczecin, Masuria, Lublin, Tarnów, Przemyśl, Bieszczady, Sandomierz, Podlasie, Zamojść, Sieradz, Łęczyca, Opoczyńska, Radom, Świętokrzyskie, Krakow, Skalne Podhale, Pogórze Karpackie, Beskid Śląski, Upper Silesia, Opole and Podole including the parishes of Żyszczyńica, Mudrygłowa and Bułakura (Diocese of Kamieniec-Podolski), Nadsanie and Bojkowszczyzna in Ukraine (Kupisiński 2009a, 178; ibidem 2010, 44).

The results of our research are published in articles and monographs, as well as during organized academic conferences in which topics on folk religiosity are addressed in papers where the results of the research conducted by our department and other academic centers in Poland are presented. In the last decade, the following conferences devoted to this subject took place, organized by the employees of the Department of History and Ethnology of Religions of the Catholic University of Lublin: October 24, 2008, "Research on African Religions and Folk Religiosity of Poland and Ukraine. The $50^{\text {th }}$ Anniversary of the Reactivation of the Department of History and Ethnology of Religions at the Catholic University of Lublin"; October 25, 2010, "Religious Studies in Poland" on the occasion of the $70^{\text {th }}$ birthday of Rev. Prof. Dr. Hab. Henryk Zimoń and handing him the Memorial Book by the employees of the Department of Religious Studies; March 10-11, 2014, "The Need for Religion. The Dynamics of Religious and Ritual Practices," along with the Chair of Religiology and Missiology: May 9-10, 2016, "Christianity in Folk Religiosity. 1050 Years after the Baptism of Poland." Papers from the conferences were in the form of expanded articles and have been published in monographs by the Publishing House of the Catholic University of Lublin. 


\section{RESEARCH METHODS AND TOPICS}

When undertaking a master's or doctoral dissertation based on collected factographic material, students of the religion studies seminar, after familiarizing themselves with the field research methodology and literature, prepare an appropriate questionnaire, which is often corrected during the exploration because new information is gained in the field. During ethnographic research, several research methods are used, since it is necessary to document why these and not other conclusions were drawn from the collected factographic material. The multi-faceted approach to the subject of research gives us the opportunity to verify our diagnosis of the phenomena, which strengthens and verifies the conclusions (Kostera 2003, 39-41, Pieter 1975, 74-81, Kupisiński 2009b, 114-22).

In ethnographic studies, interviews are a significant part of source materials. Information is collected both during a conversation, an interview organized in a more formal way, and by means of a questionnaire. The advantage of an interview is that it is possible to create conditions in which verbal or non-verbal behavior is seen in the respondents. The selection of people interviewed depends on the subject of the research. Old customs related to religious tradition, as well as those located on the threshold of religion and magic remain in the memories of the oldest generation, the people who often refer to the times of their youth and even the sayings of their parents. Interviews are also carried out among the younger generation to capture the changes taking place in folk religiosity (Kopczyńska-Jaworska 1971, 36-41, Kostyra 2003, 108-15, Kupisiński 1995, 145-46, ibidem 2009, 178-79).

The methods of analysis and literary criticism are used to report on the collected factual material so as to use it to determine the authenticity of the collected factography. The methods of participation and hidden observation also help us interpret the sources. A critical look at the collected factual material gives it a more scientific character and limits subjective elements (Majka 1975, 97, Kupisiński 2009, 178; ibidem 2009b, 122-24). In an attempt to compare the collected material with folk rites in our regions and neighboring countries, the comparative method is used (Pieter 1967, 127129, ibidem 1975, 97, Kupisiński, 2009b, 124). The phenomenological method and theological research methods are also helpful. The phenomenological method consists in observing and describing what is directly present. This approach differs from the natural attitude to be without assumptions. There is no one objective reality for phenomenologists. Using the phenome- 
nological method, one seeks to understand and explain the meaning and significance of a studied cultural or religious phenomena (Bronk 1996, 177-88, Zdybicka 1993, 109-16, Kupisiński 2009b, 124-26).

In order to better understand popular piety, other theological disciplines are also used. The respondents interviewed are believers and religious people, and therefore their material and spiritual cultural creations should be looked at in the context of the Christian values that shaped their daily lives. Religion directly influenced the creation and keeping of many customs, rituals and beliefs. Knowledge in the field of theological teachings allows the researcher of folk culture to better understand and distinguish religious practices from magical practices, which creates many problems for researchers who do not have this knowledge. Students at the religious studies seminary are characterized by theological preparation, and in their master's or doctoral theses, the theological elements of folk religiosity are strongly exposed. Such an approach to beliefs and customs in the development of folk rituals distinguishes our works from those existing at other institutions of higher education (Majka 1995, 222-23, Napiórkowski 1991, 61-62, Hajduk 2001, 223-24, Perszon 2010, 228-33).

In their dissertations, students of the Department of Religiology and Missiology attempt to draw attention to the spiritual culture and folk religiosity of the rural inhabitants, things generally ignored in previous ethnographic studies. In addition to the reconstruction and analysis of older folk rituals, researchers try to learn about modern customs, rituals and beliefs in the studied areas and pay attention to the importance of religion and the Church in creating and sustaining folk culture, as well as the impact of the liturgy on the daily religious life of the villagers. Andrzej Szyjewski stated that the department, by undertaking research on spiritual culture, became the only academic center in Poland in which "folk religiosity is the most important subject of academic research" (Szyjewski 2004, 230).

\subsection{RESEARCH ON ANNUAL RELIGIOUS FOLK PIETY PRACTICES}

Until the 1970s, Advent in folk religiosity was not only a time of pleasantly waiting for Christmas, but a period of intense religious practices, which was noticed in people's participation in numerous retreats and Advent dawn mass, and in some regions of Poland, it even had a penitential character. People refrained from smoking cigarettes, drinking alcohol, and children 
did not eat sweets. As expiation for sins, people willingly undertook penitential practices to ask God to forgive them. Active participation in the Advent liturgy aroused in the believers the spirit of sacrifice and the need for internal purification. Thanks to the ethnographic research on Advent rituals, changes occurring in folk religiosity from the past century to the present are being noticed, and this period no longer has a penitential character, but is often a more joyous anticipation of Christmas (Kupisiński 1997, 42-44; Nowak 2003, 112-14; Dudek 1988, 101-06, Węcławik 2010, 18-22, Kuczerenko 1999, 22-44).

The Christmas theme not only presents the old "Polish Bethlehem," but also the contemporary atmosphere, when often Christmas day has lost its fasting character. The research shows that most families retain their old canons on this day and refrain from eating meat dishes, maintaining the traditions of their ancestors. The way of experiencing this day shows how skillfully the Church adapted the old pre-Christian rites to the Christmas reality in Poland (Christmas tree symbolism, holy evenings, caroling). Their use made holidays rich in customs, rituals and beliefs throughout the entire liturgical year (Kupisiński 1997, 56-79, ibidem 2013, 319-26, Kuczerenko 1999, 45-66, Zadrożyńska 2000, 39-70; Smyk 2009, 66-71).

In the Christmas season, which begins at Christmas Eve in folk tradition and ends with "ostatki," there are many customs, rituals and beliefs. Some of them even originated in pre-Christian times (the cult of the dead, vegetative customs). The Christmas period has a wealth of theological ideas that have been expressed in traditional rites, including the way of preparing one's home for Christmas Eve supper, organizing nativity plays, carols, caroling bands, the cult of the dead and others. The Church assimilated some of these old customs into the season's rituals and gave them rational and theological contents, and has thus revived folk culture (Kupisiński 1997, 67-79; Zadrożyńska 2000, 58-63; Ogrodowska 2008, 90-175; Łobodziński 2010, 10-11).

The field studies conducted by the students of our specialization on Lenten rites prove that until the mid- $20^{\text {th }}$ century, this period was characterized by undertaking strict religious and ascetic practices (participation in the Way of the Cross, Lenten Lamentations, retreats, the sacraments of penance and the Eucharist, keeping a strict fast). A significant part of these dissertations is dedicated to describing Holy Week, which starts on Palm Sunday. It should be emphasized that the Church had the ability to connect religious themes with the often pre-Christian spring rituals (melting a Marzanna-the straw effigy representing winter, the role of palm trees, clatter rattles, 
painting Easter eggs). In this way, we Christianized many pre-Christian customs and folk rituals, thanks to which the Gospel message was embedded into a unique folk theology (Kupisiński 2000, 56-58, Ogrodowska 2000, 242-44, 2009, 110-58, Tymochowicz 2017, 139-42).

The Easter period is associated with many old folk, agrarian, economic and matrimonial customs and rituals. In our dissertations, we want to show Christ's victory over death not only from a theologian's point of view, but also to find this symbolism in folk rituals. The contents of the resurrection of Christ permeate folk culture, which is evident in their art, music, poetry, stories and props. In previous ethnographic studies, due to the atheistic worldview imposed in our country by the nation's authorities, this subject was often ignored, and yet the victory of Christ is seen in many customs and folk rituals (symbolism of the blessed food eaten at Easter Sunday breakfast, water, fire). Participation in religious rituals motivated them to personally resurrect to a new life (Kupisiński 2000, 109-10, Perszon 1994, 88-89, Gloger 1900, 181, Kolberg 1885, 137, Bystroń 1947, 153).

Analyzing the agrarian customs and beliefs in the annual rituals, we noticed that the villagers felt the proximity of God as the creator and the providential role that the Almighty played over them. Among others, this is evident in the maxim of farm workers that "man sows and God gives growth." Conducting field research, our researchers participated in many rituals and agrarian rites, which allowed us to better reflect on their essence and qualify them as either religious or magical. In the previous publications on agrarian rites, many magical activities were perceived, which were not always true and consistent with reality.

The blessing of grain before sowing or potatoes before planting (when the farmer made the sign of the cross over the grain and potatoes and sprinkled them with holy water, uttering the words of the prayer) was considered a magical practice not consistent with reality. The host entrusted the fate of the seeds thrown into the soil to the Creator to guard it and give them a rich harvest. Making the sign of the cross in prayer, he asked God to protect him, his farm and agricultural lands. Church holidays set the dates for working in the fields. The host's "cooperation" with God regarding the increase in land yields and prosperity on the farm can be seen in the numerous participation of village residents in services for good harvests (cross days, the rite of consecrating fields and burying fragments of Gospel texts in boundary mounds in village fields) (Kupisiński 1995, 151; 2000, 98-104; Perzson 1992, 9-12; ibidem 2010, 233; Sakowicz 2017, 230-31). 
In presenting the annual folk rituals and research subject of the department, it should be emphasized that key issues are prayers for the dead and funerals (Perszon 1999, Kupisiński 2007). Before Christianity settled into the Slavic lands, feasts in honor of the deceased were celebrated several times a year. In the Catholic Church, All Saints' celebrations (November 1) and the Day of All the Faithfully Departed (Prayers for the Dead on November 2) were the celebrations focusing on these issues. Current folk rituals for the dead include many customs and practices that, after giving them a Christian interpretation, create contemporary rituals. At the beginning of the twentieth century, the memory of the deceased was shown, among others, in the adornment of graves with spruce twigs, flowers, burning fires, arranging feasts for them, the so-called mourning dinners, giving "seniors" and the poor ritual bread.

Ethnologists see the remnants of ancient magical practices of symbolically throwing wood on the burned corpses in today's habit of throwing spruce twigs on the grave. The fire burning on the graves was supposed to illuminate the darkness, warming the cold souls, but also protect them against the effects of evil powers. Food was brought to the graves, covered with soil and left to the ancestors for consumption. Baked ritual bread, socalled crumpets, were made and given to beggars (Perszon 1999, 287-303, Kupisiński 2007, 335-48, Ogrodowska 2000, 157-260).

In the dissertations at our department, students try not to simply collect factual material referring to the past, but analyze and interpret it, paying attention to the assimilation of old customs to contemporary folk tradition. Thus, giving the poor your ritual bread is now replaced by giving the priest an offering of money for his mass prayer intentions for the dead. Older respondents claimed that by lighting the candles on the grave, souls receive relief. Today, burning candles symbolize not only eternal light and life, but above all being in heaven with the resurrected Christ who is the light of the world. The glow of the candle is to dissipate the darkness of the underworld, leading to the fullness of light that Christ is for Christians.

Today, flowers and green branches on graves symbolize eternal life, showing the innocence and final victory of the dead after their journey of life leading to the fullness of life in love and harmony, characteristic of the original state of nature that existed in paradise between man and the Creator. The cemetery is the resting place of the dead and is adorned not only because of their memory, but above all because the liturgy is celebrated there and prayers are offered. Graves holding the ashes of relatives, decorated 
with flowers, bouquets and burning candles are an expression of reverence for the dead, and the best proof of remembering them is prayer (Perszon 1999, 290-99, Kupisiński 2007, 336-40, Plucińska 2014, 228-33).

At present, All Souls' Day reveals the testimony of the love of those who are alive expressed to those who have passed away; this is a love that is stronger than death. A rational justification of belief in eternal life encourages people to daily remember their dead, offer them heartfelt gifts, meaning the personal prayers of a believer and the prayer of the Church community. The contemporary, formal contents of celebrating the memory of the deceased are defined by the liturgy of the Church, and the old customs and beliefs related to the deceased are experienced in the spirit of New Testament soteriology (Plucińska 2014, 231-33, Kupisiński 2007, 345-52, Perszon 1999, 298-301).

Our field research shows that remembering the dead is not only limited to funeral rituals, but is preserved throughout annual rituals, and today it is part of the liturgy. Elements of praying for the dead to various degrees in the form of customs and beliefs can be observed throughout the calendar year. A special place in folk religiosity and the memory of the deceased take All Saints' celebrations and All Souls' Day together with the octave of this holiday. The research shows that despite the disappearance of old funeral practices and praying for the dead, traditions that are rejected by modern rationalism, new customs related to death are observed and inscribed into the Church's liturgy (frequent Mass intentions for the dead, indulgences for the suffering souls in purgatory, reciting prayers for the dead, and visiting graves) as man's response and expecting eternal life (Plucińska 2014, 23133, Perszon 1999, 301, Kupisiński 2005, 207-08).

\subsection{RITES OF PASSAGE}

In the Department of Religiology and Missiology, we also deal with issues related to rites of passage, including topics related to wedding and funeral rites. Wedding ceremonies in Poland are a topic that was undertaken in three master's theses, one post-graduate licentiate and a monograph by Zdzisław Kupisiński and Jan Łuczkowski: Customs, Rituals and Wedding Beliefs in Opoczno Region. Traditions and the Present.

Both in Polish tradition and in cultures specific to other countries, marriage is accompanied by a wealth of customs, rites and beliefs, constituting 
of specific customs characteristic of a certain region or country. In the creation of this relationship, religion, economics and customs characteristic of the local community or ethnic group are important and taken into consideration. Therefore, in addition to presenting the various stages that make up the wedding ritual, meaning courting, visiting or arrangements, match-makers, engagements, announcements, wedding invitations, a bachelor and bachelorette party, blessings, the wedding procession, marriage ceremony, wedding feast, wedding games, moving or settling in together, we also draw attention to the spiritual and religious values of marriage (Kupisiński 2016, 23-167; ibidem 2017b. 68-69; Plucińska 2014, 16-77; Tymochowicz 2013, 56-66).

For Christians, marriage has the character of a sacrament and is a sign of the unity between God and man in the Person of the God-Man. For Catholic families, marriage in the Church is of great importance. They prepare for the liturgical rites according to the generally accepted scenario, and the nonliturgical activities are accompanied by a rich beliefs sphere passed down from generation to generation, where the rituals aimed to multiply happiness and God's blessing for a young couple (Kupisiński 2016, 97-111; ibidem 2017a, 58-68; Plucińska 2014, 44-57; Ogrodowska 2007, 170-81).

Dissertations are based on source material primarily referring to the students' and academic staff's own ethnographic stationary field research studies. We not only recreate the old wedding ceremony scenario, but also present the ongoing moral changes related to both marriage preparation and the wedding itself, as well as transformations related to the family model. As more and more people break with tradition, they put more emphasis on achieving their own needs, autonomy and independence in the relationships. Old norms and traditions are taken lightly and this is gaining approval. Our department seeks to emphasize the sacramental meaning of marriage, and it seems to be our duty to revive this ritual through our reports, given that in the modern world, one can observe the desacralization of behaviors, their attitudes and the function of religion. The emphasis on religious contents in wedding ceremonies differs in our studies from those developed at other universities or in the research created by ethnologists or religious scholars (Kupisiński 2017a, 70-71; Plucińska 2014, 47-51).

Recently, the issues of death, funeral rituals and prayers for the deceased have been covered by our stationary ethnographic field researchers on a wider scale (Opoczno, Radom, Kaszuby, Podkarpacie, Podlasie, and Lublin regions). Death, as an independent threshold phenomenon, is one and the same, regardless of a person's age or the place where it happens. The subject 
of death appears in everyday conversations, usually when someone close to us passes away or when we read a newspaper's obituary. Although we are aware that everyone will die sooner or later, we are uneasy at the thought of our own death.

Usually, every person would like to postpone it "for later."

Analyzing the phenomenon of death, one perceives a certain complexity resulting from the occurrence of beliefs that go back to pre-Christian and also modern times, based on the biblical message and the teachings of the Catholic Church. Our research sought to present what death is to the inhabitants of the studied regions. An attempt was made to answer the question of what is behind their external form, and to find the sources of the rich sphere of religious funeral rituals. By undertaking research on funeral rituals, one can still recover or reconstruct ancient customs and rituals based on information obtained from the oldest generation, as well as references to old prayer books or manuscripts containing songs and prayers used during services performed for the dead (Kupisiński 2006, 145-47; ibidem 2007, 44648; Perszon 1999, 375-85).

The collected factographic material is a valuable documentation of funeral rites. By undertaking research on this issue, we managed to gather relevant information showing the traditional model of dying and became familiar with the ideas of inhabitants of these regions about death and the afterlife. Showing the sphere of belief associated with death required learning the values system of the interviewed and their principle life axioms, which enabled us to make a more accurate interpretation of the ideas that lay in the funeral customs and rituals. Former eschatic beliefs, although in some cases inconsistent with Christian teachings (signs announcing death, methods for accelerating dying), indicate the coexistence of old beliefs and modern rituals related to the mystery of death and the afterlife (Perszon 1999, 376-85; Kupisiński 2007, 436-41).

The annual rites, as well as the rites of passage and accompanying religious practices presented in the dissertations and publications of our academic employees, show the richness of a village's spiritual culture. The socio-economic changes taking place in the last century and the progressing modernization of village life has led to a significant cultural transformation, 
and also to forgetting many old rituals and customs, negatively affecting and weakening folk religiosity.

For many centuries, Christmas Eve was characteristically a family gathering, the day considered to be the most beautiful in the whole year. Supper together and sharing the wafer, wishing each other blessings, leaving an empty space at the table for someone who might be absent and singing carols united everyone at the meal. The treasure of religious and cultural traditions handed down from generation to generation made the family home, if possible, the place where everyone gathered from distant corners of Poland, and even from outside our country, to reactivate the folk tradition and reunite family members with loved ones in order to greet God the Savior who comes to man. Objects and symbolic acts present during the Christmas Eve supper or in preparing the Easter breakfast basket created a family setting, emphasizing bonding and closeness, which, combined with religious contents, give these holidays a special atmosphere.

In undertaking the topics of funeral rituals, the experience of death in folk tradition has been shown, which consists of its announcements, the moment of dying, death, preparing the body of the deceased, the prayer vigil at the side of the deceased and the burial. Attention is paid to the old folk beliefs connected with death entering into the contemporary religious contents based on the renewed liturgy of the Catholic Church. These two traditions combine to show a living faith in the afterlife, which gives meaning to human existence on earth. Belief in the afterlife is confirmed by people's need to remember the dead throughout the entire calendar year. The dead are invoked on family and church holidays, believing in their real presence and the mutual penetration of the extrasensory world with the material world.

Nurturing family rituals and popular piety developed over generations and is the foundation and expression of the continuity of our family and religious heritage as well as the cultural and ethnic identity of country village residents, including societies where Polish families live outside our country.

\section{BIBLIOGRAPHY}

Bronk, Andrzej (1996). Nauka wobec religii. Teoretyczne podstawy nauk o religii [Science Towards Religion. Theoretical Foundations of Religious Studies]. Lublin: TN KUL, 1996.

BYstroŃ, Jan Stanisław (1972). Kultura ludowa [Folk Culture]. Warsaw: Trzaska, Evert i Michalski. 
DudEK, Antoni (1988). „Zwyczaje i obrzędy adwentowe na ziemi pszczyńskiej” [“Customs and Advent Rituals on the Lands of Pszczyna"]. In Z badań nad religijnościq ludowa [From Research on Folk Religiosity], edited by Henryk Zimoń, 101-15. Warsaw: Verbinum.

Gloger, Zygmunt (1900). Rok polski w życiu, tradycji i pieśni [A Year of Life, Tradition and Songs in Poland]. Warsaw: Wydawnictwo Jan Fiszer.

HAJDUK, Zygmunt (2001). Ogólna metodologia nauk [General Academic Methodology]. Lublin: TN KUL.

Catechism of the Catholic Church (2012). Poznań: Pallottinum (CCC).

KolberG, Oskar (1885). Dzieta wszystkie, t. XXIV: Mazowsze, cz. 1 [Collected Works, vol. XXIV: Mazowsze, part 1]. Kraków: Ludowa Spółdzielnia Wydawnicza Polskie Wydawnictwo Muzyczne.

KOPCZYŃSKA-JAWORSKA, Bronisława (1971). Metodyka etnograficznych badań terenowych [Methodology of Ethnographic Field Studies]. Warsaw-Lódź: Państwowe Wydawnictwo Naukowe.

Kostera, Monika (2003). Antropologia organizacji. Metodologia badań terenowych [Anthropology of Organization. Methodology of Field Research]. Warsaw: Wydawnictwo Naukowe PWN.

KUCZERENKO, Maria (1999). Zwyczaje, obrzędy oraz wierzenia adwentowe i bożonarodzeniowe w parafii Gwizdów [Customs, Rituals and Advent and Christmas Beliefs in the Parish of Gwizdów]. Gwizdów: Parafia Rzymskokatolicka w Gwizdowie [Roman Catholic Parish in Gwizdów].

KUPISIŃSKI, Zdzisław (1995). "Badania etnograficzne nad religijnością ludową w regionie opoczyńskim" [Ethnographic Research on Folk Religiosity in the Opoczno Region]. In Między antropologia a filozofia $i$ historia. Prezentacja lubelskiego środowiska antropologii kulturowej [Between Anthropology, Philosophy and History. A Presentation of Lublin's Cultural Anthropology Milieu], edited by Krzysztof Jarosław Brozi, 145-52. Lublin: Wydawnictwo UMCS.

KuPISIŃSKI, Zdzisław (1997). Adwent i Boże Narodzenie w regionie opoczyńskim. Studium religijności ludowej [Advent and Christmas in the Opoczno Region. A Study of Folk Religiosity].Warsaw: Verbinum.

KuPISIŃsKI, Zdzisław (2000). Wielki post $i$ Wielkanoc $w$ regionie opoczyńskim. Studium religijności ludowej [Lent and Easter in the Opoczno Region. A Study of Folk Religiosity].Warsaw: Verbinum.

KUPISIŃSKI, Zdzisław (2005). "Elementy zaduszkowe w dorocznej obrzędowości ludowej regionu opoczyńskiego" ["Elements of Prayers for the Dead in the Annual Folk Rite of the Opoczno Region"]. In Werbiści a badania religiologiczne [The Verbists and Religiology Studies], edited by Adam Wąs SVD, 189-211. Warsaw: Verbinum.

KuPISIŃSKI, Zdzisław (2006). "Zwyczaje i obrzędy związane ze śmiercią i pogrzebem według tradycji w Radomskiem" ["Customs and Rituals related to Death and Burial according to Traditions in Radomsko"]. In Rytuat. Przeszłość i teraźniejszość [Rituals. Past and Present], edited by Marian Filipiak, Maciej Rajewski, 145-67. Lublin: Wydawnictwo UMCS.

KUPISIŃSKI, Zdzisław (2007). Śmierć jako wydarzenie eschatyczne. Zwyczaje, obrzędy i wierzenia pogrzebowe oraz zaduszkowe mieszkańców regionu opoczyńskiego i radomskiego [Death as an Eschatic Event. Customs, Rituals and Funeral Beliefs as well as Prayers for the Dead among Residents of the Opoczno and Radom Regions]. Lublin: Wydawnictwo KUL.

KUPISIŃSKI, Zdzisław (2009a). "Badania Katedry Historii i Etnologii Religii nad religijnością ludową" ["Studies on Folk Religion at the Department of History and Ethnology of Religions"]. In Badania nad religiami Afryki oraz religijnościa ludowa Polski i Ukrainy [Studies 
on African Religions and Popular Piety in Poland and Ukraine], edited by Henryk Zimoń SVD, Zdzisław Kupisiński SVD, Stanisław Grodź SVD, 175-95. Lublin: TN KUL.

KUPISIŃSKI, Zdzisław (2009b). "Metody badawcze stosowane w pracach dydaktycznych z etnologii religii" ["Research Methods Used in Didactic Works on the Ethnology of Religion"]. Roczniki Teologii Fundamentalnej i Religiologii [Annals of Fundamental Theology and Religiology] 56, 1: 111-29.

KuPISIŃSKI, Zdzisław (2010a). "Fenomen polskiej religijności ludowej” [“The Phenomenon of Polish Folk Religiosity"]. Ateneum Kapłańskie 155, 2/609: 216-27.

KUPISIŃSKI, Zdzisław (2010b). “Życiorys i działalność naukowa księdza profesora Henryka Zimonia SVD" [The Biography and Academic Activity of Fr. Professor Henryk Zimon SVD]. In Pluralizm kulturowy i religijny wspótczesnego świata. Księga pamiątkowa dedykowana księdzu profesorowi Henrykowi Zimoniowi SVD w 70. rocznice urodzin [Cultural and Religious Pluralism in the Modern World. Memorial Book Dedicated to Fr. Henryk Zimoni SVD on his $70^{\text {th }}$ Birthday], edited by Zdzisław Kupisiński, Stanisław Grodź, 22-45. Lublin: Wydawnictwo KUL.

KuPIsIŃski, Zdzisław (2013). "Wigilia Świąt Bożego Narodzenia jako wyraz tożsamości kulturowej mieszkańców regionu opoczyńskiego" ["Christmas Eve as an Expression of the Cultural Identity of the Inhabitants of the Opoczno Region"]. In Niematerialne dziedzictwo kulturowe. Identyfikacja-dokumentacja-ochrona-interpretacja-pojęcia-poglady [Intangible Cultural Heritage. Identification-Documentation-Protection-Interpretation-Concepts - Views], edited by Krzysztof Braun, 316-28.

Warszawa-Węgorzewo: Muzeum Historii Polskiego Ruchu Ludowego [Museum of the History of the Polish Folk Movement].

KuPISIŃSKI, Zdzisław, Łuczkowski, Jan (2016). Zwyczaje, obrzędy i wierzenia weselne w Opoczyńskiem. Tradycja a wspótczesność [Customs, Ceremonies and Wedding Beliefs in Opoczno Region. Traditions and the Present]. Opoczno: Muzeum Regionalne w Opocznie.

KUPISIŃSKI, Zdzisław (2017a). "Małżeństwo sakramentalne w polskiej obyczajowości ludowej” [Sacramental Marriage in Polish Folk Customs]. In Chrześcijaństwo w religijności ludowej1050 lat po chrzcie Polski [Christianity in Folk Religiosity. 1050 Years after the Baptism of Poland], edited by Zdzisław Kupisiński SVD, 57-73. Lublin: Wydawnictwo KUL.

KuPIsIŃsKI, Zdzisław (2017b). "Zwyczaje zalotne i matrymonialne w obrzędowości weselnej jako wyraz tożsamości mieszkańców Opoczyńskiego" ["Flirtatious and Matrimonial Customs in Wedding Ceremonies as an Expression of the Identity of the Inhabitants of Opoczno Region"]. In Wspótczesne konteksty tożsamości społeczno-kulturowych, vol. 10 [Contemporary Contexts of Socio-Cultural Identities, vol. 10], edited by Małgorzata Dziekanowska, Marta Wójcicka, 59-71. Lublin: Wydawnictwo UMCS.

ŁoBodziŃski, Józef (2010). "Bogactwo ludowej teologii i pobożności” [“The Wealth of Folk Theology and Devotion”]. Ateneum Kapłańskie 155, 1/608: 7-12.

ŁUKASZYK, Romuald (1968). "Pięćdziesięciolecie teologii fundamentalnej na KUL (1919-1968)" [Fifty Years of Fundamental Theology at KUL (1919-1968)]. Roczniki Teologiczno-Kanoniczne 15, 2: 5-53.

MAJKA, Józef (1995). Metodologia nauk teologicznych [Methodology of Theological Studies]. Wrocław: Wydawnictwo TUM.

NAPIÓRKowski, Stanisław Celestyn OFMConv (1991). Jak uprawiać teologię? [How to Practice Theology?]. Wrocław: Wydawnictwo Wrocławskiej Księgarni Archidiecezjalnej. 
NowAK, Józef (2003). Adwent i Boże Narodzenie w regionie tomaszowskim. Studium religijności ludowej [Advent and Christmas in the Tomaszów Region. A Study of Folk Religiosity]. Lublin: TN KUL.

Ogrodowska, Barbara (2000). Zwyczaje, obrzędy i tradycje w Polsce. Maty stownik [Customs, Rituals and Traditions in Poland. A Small Dictionary]. Warsaw: Verbinum.

Ogrodowska, Barbara (2007). Polskie tradycje i obyczaje rodzinne [Polish Traditions and Family Customs]. Warsaw: Sport i Turystyka-MUZA SA.

OGRODOwSKA, Barbara (2008). Radość wszelkiego stworzenia. Rzecz o adwencie i Bożym Narodzeniu-historia, tradycja, obyczaj polski [The Joy of all Creation. About Advent and Christmas, Polish History, Traditions and Customs]. Warsaw: Verbinum.

Ogrodowska, Barbara (20094). Polskie obrzędy i zwyczaje doroczne [Polish Rites and Annual Customs]. Warsaw: Sport i Turystyka-MUZA SA.

Perszon, Jan (1992). Na imie Bosczi. Zwyczaje i obrzedy agrarne na Ziemi Wejherowskiej [In the Name of Boschi. Customs and Agrarian Rites on the Wejherowo Land]. Luzino: Druk Pektor Lublin.

Perszon, Jan. (1994). Jastrë na helu. Wielki Post i okres Wielkanocy na Pótwyspie Helskim [Jastre on Hel. The Lent and Easter Seasons on the Hel Peninsula]. Lublin-Jastarnia: Urząd Miasta i Gminy Jastarnia.

Perszon, Jan. (1999). Na brzegu życia i śmierci. Zwyczaje, obrzędy oraz wierzenia pogrzebowe i zaduszkowe na Kaszubach [On the Edge of Life and Death. Customs, Rituals, Funeral and Praying for the Dead in Kashubia]. Pelplin-Lublin: TN KUL.

Perszon, Jan (2010). "Pobożność ludowa-zmierzch czy transformacja?” [Popular Piety. Dusk or Transformation?] Ateneum Kapłańskie 155, 2/609: 228-46.

PIETER, Józef (1975). Zarys metodologii pracy naukowej [Outline of the Methodology of Academic Research Work]. Warsaw: Wydawnictwo Naukowe PWN.

PIETER, Józef (1967). Ogólna metodologia pracy naukowej [General Methodology of Academic Work]. Wrocław-Warsaw-Kraków: Zakład Narodowy im. Ossolińskich-Wydawnictwo Polskiej Akademii Nauk.

PluciŃSKA, Aldona Jadwiga (2014). Polskie zwyczaje rodzinne [Polish Family Customs]. Łódź: Księży Młyn Dom Wydawniczy.

SAKOwicz, Eugeniusz (2017). "Polska ludowa teologia i pobożność" [Polish Folk Theology and Piety]. In Chrześcijaństwo w religijności ludowej-1050 lat po chrzcie Polski [Christianity in Folk Religiosity. 1050 Years after the Baptism of Poland], edited by Zdzisław Kupisiński SVD, 227-233. Lublin: Wydawnictwo KUL.

SMYK, Katarzyna (2009). "Bożonarodzeniowa choinka-domową osią świata" [The Christmas Tree. The World's Axis at Home]. In $O$ wyższości świąt Bożego Narodzenia [On the Superiority of Christmas Holidays], edited by Aleksandra Kędzierska, Irmina Wawrzyńczyk, 61-75. Lublin: Wydawnictwo UMCS.

SZYJEWSKI, Andrzej (2004). "Religious Ethnology in Poland. The Issues of Folk Religion." In Ethnology of Religion; Studies in Ethnology, edited by Gábor Barna, 222-48. Budapest-Szeged.

Tyмосноwicz, Mariola (2013). Lubelska obrzędowość rodzinna w kontekście wspótczesnych przemian [Lublin's Family Rituals in the Context of Contemporary Transformations]. Lublin: Lubelskie Towarzystwo Naukowe. 
Tyмосношicz, Mariola (2017). "Posty religijne w kulturze ludowej” ["Religious Fasting in Folk Culture”]. Roczniki Teologiczne 64, 9: 137-146.

WĘCŁAWIK, Józef (2010). “Tradycja i zmiana obrzędowości adwentowej w perspektywie pobożności ludowej" ["Tradition and Changes in Advents Rituals in the Perspective of Popular Piety"]. Ateneum Kapłańskie 155, 1/608: 13-25.

ZADROŻYŃSKA, Anna (2000). Światy, zaświaty. O tradycji świętowań w Polsce [Worlds and the Netherworld. On Holiday Traditions in Poland]. Warsaw: Wydawnictwo Książkowe Twój Styl.

ZDYBICKA, Zofia Józefa (1993). Człowiek i religia. Zarys filozofii religii [Man and Religion. An Outline of the Philosophy of Religion]. Lublin: TN KUL.

ZIMoŃ, Henryk (1980). "Działalność Instytutu Anthropos" ["The Activity of the Anthropos Institute"]. In Działalność Instytutu Anthropos w dziedzinie lingwistyki, etnologii i religioznawstwa [The Anthropos Institute's Work in Linguistics, Ethnology and Religious Studies], edited by Henryk Zimoń, 212-23. Pieniężno: Seminarium Duchowne Księży Werbistów.

ZIMoŃ, Henryk (1985). "Religioznawstwo w szkołach średnich i wyższych” [,Religious Studies in Secondary and Higher Schools"]. Zeszyty Naukowe KUL 28, 3-4: 153-161.

ZIMoŃ, Henryk (1989-1990). "Działalność dydaktyczna Katedry Historii i Etnologii Religii KUL" [Didactic Activity at the Department of History and Ethnology of Religions at KUL]. Lud 73, 251-255.

ZIMoŃ, Henryk (2009). "Badania Katedry Historii i Etnologii Religii nad tradycyjnymi religiami Afryki Subsaharyjskiej" ["Studies of the Department of History and Ethnology of Religions on the Traditional Religions of Sub-Saharan Africa"]. In Badania nad religiami Afryki oraz religijnościa ludowa Polski i Ukrainy [Studies on African Religions and Folk Piety in Poland and Ukraine], edited by Henryk Zimoń SVD, Zdzisław Kupisiński SVD, Stanisław Grodź SVD, 11-37. Lublin: TN KUL.

\section{Translated by Jan Kobytecki}

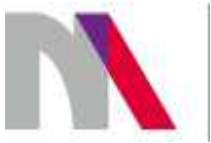

The preparation of the English version of Roczniki Teologiczne (Annals of Theology) and its publication in electronic databases was financed under contract no. 836/P-DUN/2018 from the resources of the Minister of Science and Higher Education for the popularization of science. 